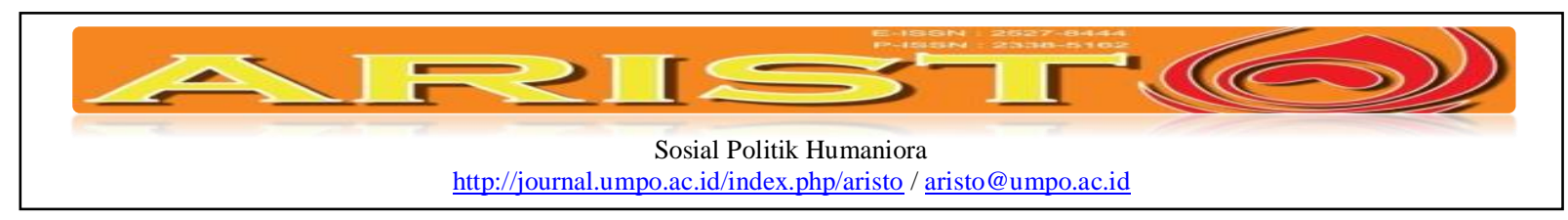

\title{
Membangun Sistem Rekrutmen Calon Pegawai Negeri Sipil Pada Era Otonomi Daerah
}

\author{
Mahathir Muhammad Iqbal \\ Ilmu Pemerintahan, FISIP, Universitas Islam Raden Rahmat Malang \\ iqbalzmm@yahoo.com
}

\begin{abstract}
The concept of decentralization which manifests the concept of local autonomy has implications for efforts to strengthen regional governance based on local potential, including strengthening resource management apparatus is characterized by the process and implementation of personnel management started from procurement personnel consisting of; planning, formation, recruitment and selection, development, promotion, remuneration, discipline, and dismissal or retirement. Procedures and implementation of recruitment candidates for Civil Servants (CPNS) from internal sources (Workers Honorary) and from external sources (the general public) or a common path, and potentially very susceptible to spoil the practice of system and Nepo system. One of the efforts that must be made to minimize all forms of deviation in the framework of the process of recruitment and implementation is to implement a merit system, as the antithesis of giving jobs on the basis of race, ethnicity, religion, political award, gender discrimination, personal favoritism, or the selection of equipment valid.

Keywords: System Recruitment, Candidate for Civil Servants (CPNS), Local Government and the Merit System, Bureucracy.
\end{abstract}

\begin{abstract}
Abstraksi
Konsep desentralisasi yang memanifestasikan konsep otonomi daerah yang berimplikasi terhadap upaya penguatan penyelenggaraan pemerintahan daerah yang berbasis pada potensi lokal, termasuk penguatan manajemen sumberdaya aparatur yang ditandai dengan proses dan pelaksanaan manajemen kepegawaian ini dimulai dari pengadaan pegawai yang terdiri dari; perencanaan, formasi, rekrutmen dan seleksi, pengembangan, promosi, remunerasi, disiplin, dan pemberhentian atau pensiun. Prosedur dan pelaksanaan sistem rekrutmen Calon Pegawai Negeri Sipil (CPNS) dari sumber internal (Tenaga Honorer) dan dari sumber eksternal (masyarakat umum) atau jalur umum, sangat rentan dan potensial terhadap praktek spoil system dan nepo system. Salah satu upaya yang harus dilakukan untuk meminimalisir segala bentuk penyimpangan dalam rangka proses dan pelaksanaan rekrutmen adalah dengan cara menerapkan merit system, sebagai antitesis dari memberikan pekerjaan atas dasar ras, etnis, agama, penghargaan politik, diskriminasi jenis kelamin, favoritisme personal, ataupun peralatan seleksi yang valid.
\end{abstract}

Kata Kunci: Merit System, Pemerintahan Lokal, Disentralisasi, Otonomi Daerah, Birokrasi

\begin{tabular}{|ll|}
\hline Submite & $:$ 10 Jan 2017 \\
Review & $:$ 20 April 2017 \\
Accepted & $:$ 30 Mei 2017 \\
Surel Corespondensi & $:$ hayat.150318@gmail.com \\
\hline
\end{tabular}

\section{Pendahuluan}

Perubahan lingkungan strategis abad ke-21 mengakibatkan perubahan besar dalam berbagai segi kehidupan bangsa Indonesia, di antaranya adalah ketersediaan sumberdaya 


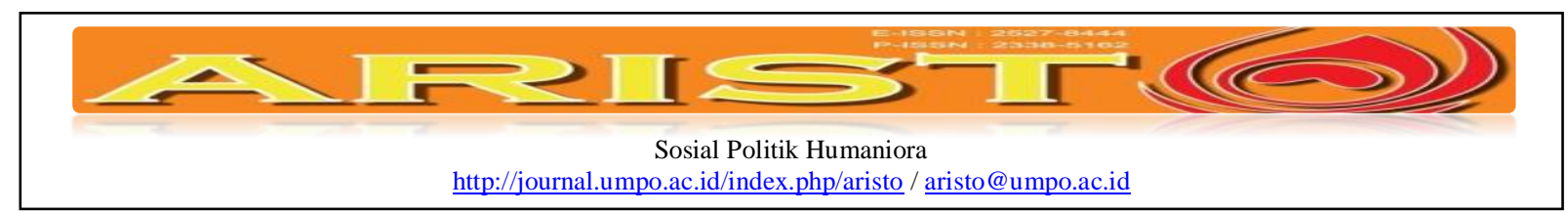

Pegawai Negeri Sipil (PNS) pada level Pemerintah maupun level Pemerintah Daerah sebagai ujung tombak penyelengaraan pemerintahan di Indonesia. Dalam pelaksanaan pembangunan nasional, peranan Pegawai Negeri Sipil (PNS) selaku aparat pemerintah sangat penting, mengingat bahwa eksistensi Pegawai Negeri Sipil (PNS) merupakan salah satu unsur paling dominan dan strategis dalam proses pencapaian tujuan Nasional. Sebab itu diperlukan suatu usaha untuk menjaga ketersediaan dan peningkatkan kualitas Pegawai Negeri Sipil (PNS) agar dapat menjamin mutu Pegawai Negeri Sipil (PNS) yang bekerja pada instansi pemerintah. Untuk mendapatkan pegawai yang berkompeten diperlukan adanya sistem pengadaan pegawai agar dapat memperoleh Pegawai yang efisien dan efektif dalam menjalankan tugas dan fungsinya dalam rangka meningkatkan efisiensi dan efektifitasnya agar tujuan yang ditetapkan dapat terwujud. Landasan pengadaan Pegawai Negeri Sipil ini di atur oleh Undang-Undang Nomor 43 Tahun 1999 yakni Undang-undang tentang pokok-pokok Kepegawaian dan Peraturan Pemerintah Nomor 98 tahun 2000 dan mengalami perubahan yaitu Peraturan Pemerintah Nomor 11 Tahun 2002 tentang pengadaan Pegawai Negeri Sipil.

Hasil penelitian Madelin, tentang kajian “Analisis Kebijakan Rekrutmen dan Seleksi PNS (2008)" membuktikan bahwa proses penerimaan PNS di Indonesia masih diwamai penyuapan dan nepotisme, sehingga saat diterima ada motif untuk mengembalikan modal yang berdampak pada korupsi. Sebagaimana Madelin menulis dalam ringkasan disertasi itu bahwa rekrutmen dan seleksi PNS cenderung nopotisme. Hal ini berdasarkan rendahnya kualitas pegawai negeri sipil (PNS) yang dihasilkan dari proses rekrutmen PNS yang buruk dan tidak profesional dimana proses penerimanannya masih diwamai KKN (kolusi, korupsi, nepotisme) melalui jalinan politik, keluarga dan hubungan kekerabatan.

Temuan Madelin berbeda dengan penelitian Gossett (2002) yang berjudul 'Civil Service Reform: The Case of Georgia', penelitian ini adalah meneliti tentang reformasi aparatur di negara Georgia melalui pemberlakuan UU Reformasi Sistem Merit. Hasil penelitian ini yaitu dengan pemberlakukan sistem merit telah membawa perubahan mulai dari rekrutmen sampai pada penempatan, desen-tralisasi atau tanggungjawab moral pegawai. Reformasi ini juga telah meminimalkan campur tangan dan pengaruh politik dalam manajemen kepegawaian negara. Reformasi kepegawaian yang dimaksud adalah adalah membebaskan pegawai dari kroni politik sehingga mereka dapat menjadi profesional dalam melaksanakan tugas sebagai pelayan publik. 


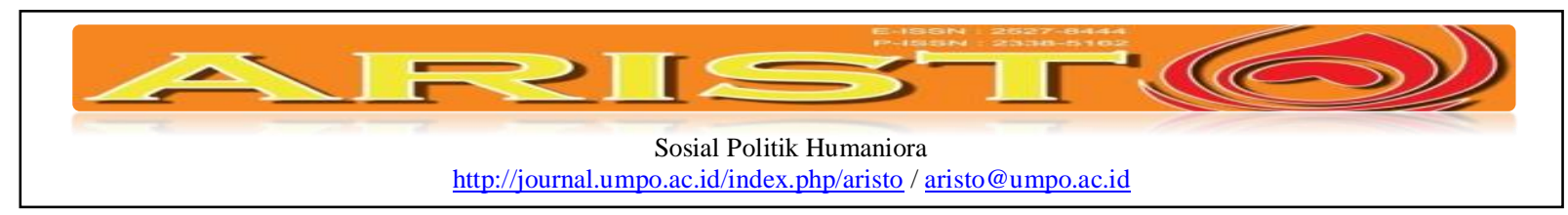

Dengan sistem merit yang lepas dari intervensi politis, maka proses rekrutmen dilakukan mulai dari penentuan kebijakan pengadaan pegawai sampai pada pelaksanan dilakukan melalui proses penjaringan, seleksi dan penempatan hanya pada mereka yang secara objektif memang unggul karena semua proses tersebut dilaksanakan secara terbuka dan diketahui oleh masyarakat. Selain itu kebijakan ini mampu mengubah 'karakter pegawai dan membebaskan mereka dari berbagai bentuk diskriminasi ras, kulit, asal daerah, seks, usia, kecacatan dan agama.

Masalah umum yang seringkali muncul dalam rekrutmen CPNS di era Orde Baru adalah maraknya praktek perkoncoan, percaloan dan semacamnya. Praktek demikian telah berlangsung lama, karena tertanamnya pemahaman bahwa PNS adalah profesi terhormat di tengah-tengah masyarakat, yang di masa lalu (masa patrimonial) pegawai negeri adalah penguasa yang dilayani oleh rakyat. Bila disederhanakan, ada dua praktek tercela yang kerap kali terjadi dalam rekrutmen CPNS, yakni kolusi dan korupsi. Kolusi disini dapat diartikan sebagai adanya persekongkolan antara para pelamar CPNS dengan pihak lain yang menjanjikan akan meluluskan dan meloloskannya menjadi CPNS dengan imbalan tertentu. Sedang makna korupsi disini lebih kepada korupsi jabatan yakni orang yang karena jabatannya dalam struktur pemerintahan tertentu melakukan persekongkolan dengan pelamar CPNS untuk meluluskan dan meloloskan menjadi CPNS tanpa melalui standar prosedur yang berlaku. Praktek kolusi dan korupsi bisa saja dilakukan bersamaan karena kedua konsep tersebut sangat tipis perbedaannya, identik dengan praktek spoil sytem yang telah membudaya di tengah-tengah masyarakat.

Di Era reformasi kehidupan PNS banyak berubah, tuntutan untuk bekerja sesuai dengan keahlian dan kemampuannya. PNS sekarang juga mendapat tanggungjawab yang berat terutama dalam menjalankan tugas dan tanggung-jawabnya sebagai abdi negara. Pengawasan masyarakat yang semakin menunjukkan kemajuannya menjadikan PNS harus bekerja dengan berbasis kinerja. Selain itu juga harus bekerja secara transparan, akuntabel dan menjunjung tinggi nilainilai demokrasi. Apalagi memasuki era otonomi daerah keberadaan PNS semakin tidak jelas terutama dengan buruknya manajemen sistim kepegawaian di daerah. Kondisi ini yang seringkali tidak dibarengi dengan peningkatan standar kompetensi PNS. Kenyataan ini mengakibatkan PNS tidak memiliki standar kerja yang jelas. Jadi tidak heran apabila masih adanya PNS terlihat sering bermain game ataupun hanya duduk-duduk sambil "ngerumpi". Kenyataan ini masih banyak terlihat di beberapa lembaga pemerintahan. 


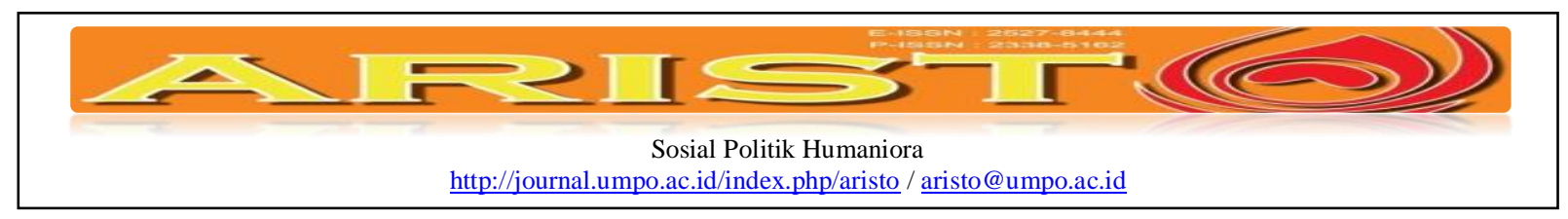

Kondisi demikian sebenarnya tidak terjadi kalau pemerintah mampu merencanakan kebutuhan PNS secara tepat dan profesional. Berbagai persoalan yang berkaitan dengan keberadaan PNS sangat kompleks. Permasalahan tersebut dimulai dari proses rekrutmen yang tidak mengedepankan analisis dan kebutuhan, sistem penempatan yang tidak memperhatikan kinerja, sistem penggajian dan penghargaan yang kurang memperhatikan prestasi dan kinerjanya. Belum lagi permasalahan karier PNS, sistem pendidikan dan pelatihan serta berkaitan dengan sistim pemberhentian PNS. Berbagai permasalahan tersebut diperlukan langkah-langkah yang nyata dalam mewujudkan aparatur birokrasi yang bersih, profesional dan berperan sebagai pelayan masyarakat. Fenomena faktual tentang animo Masyarakat untuk menjadi Pegawai Negeri Sipil (PNS) nampak masih terus meningkat dari tahun ke tahun. Hal ini sangat terlihat dengan jelas dari membludaknya aktivitas masyarakat mengurus berbagai kelengkapan administrai untuk memenuhi syarat di terima sebagai Calon Pegawai Negeri Sipil (CPNS). Selain itu aktivitas masyarakat juga cukup ramai mengikuti prosedur penerimaan CPNS tersebut. Sistem rekruitmen Calon Pegawai Negeri Sipil (CPNS) selama ini yang mengutamakan pendekatan normati (Regulasi) nampak belum sepenuhnya dipedomani oleh pemerintah daerah/instansi terkait terutama pihak-pihak (recruiter) yang diberikan wewenang untuk melakukan rekruitmen Calon Pegwai Negeri Sipil (CPNS). Selain itu, aktivitas dalam proses rekruitmen masih di warnai saling intervensi dan terjadi comflc interest antara pejabat legislatif dan eksekutif dalam mempengaruhi keputusan penerimaan Calon Pegawai Negeri Sipil (CPNS). Kedudukan Pegawai Negeri Sipil (PNS) sangatlah urgen yang pelaksanaan perekrutannya mengacu pada Peraturan Pemerintah Nomor 98 Tahun 2000 jo Peraturan Pemerintah Nomor 11 tahun 2002, perlu menerapkan prinsip merit system dalam proses dan pelaksanaan sistem rekrutmen Calon Pegawai Negeri Sipil (CPNS).

\section{Metode dan Kajian Pustaka}

Akar permasalahan buruknya kepegawaian negara di Indonesia pada prinsipnya terdiri dari dua hal penting: (1) persoalan internal sistem kepegawaian negara itu sendiri, (2) persoalan eksternal yang mempe-ngaruhi fungsi dan profesionalisme kepegawaian negara, dan situasi problematik terkait dengan persoalan internal sistem kepegawaian dapat dianalisis dengan memperhatikan subsistem yang membentuk kepega-waian negara.

Mahatir Muhammad Iqbal, Membangun Sistem Rekrutmen Calon Pegawai Negeri Sipil Pada Era Otonomi Daerah /07/Vol. 05/No. 02 Juni 2017 


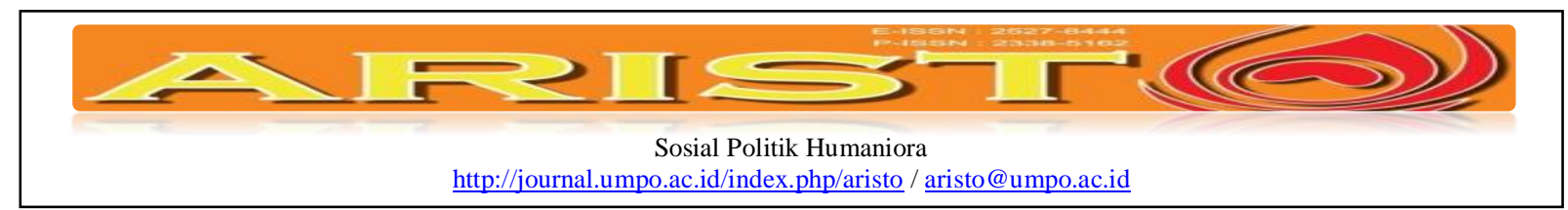

Subsistem kepegawaian negara terdiri dari: (1) rekrutmen, (2) penggajian dan reward, (3) pengukuran kinerja, (4) promosi jabatan, (5) pengawasan. Kegagalan pemerintah untuk melakukan reformasi terkait dengan subsistem-subsistem tersebut telah melahirkan birokrat-birokrat yang dicirikan oleh kerusakan moral (moral hazard) dan juga kesenjangan kemampuan untuk melakukan tugas dan tanggungjawabnya (lack of competencies) Prasojo, (2006).

\section{Pembahasan dan Analisis}

Prasojo, (2006), mengeukakan bahwa terkait dengan persoalan rekrutmen, dapat disebutkan beberapa situasi problematik yang dihadapi oleh birokrasi di Indonesia. Proses rekrutmen masih belum dilakukan secara profesional dan masih terkait dengan hubunganhubungan kolusi, korupsi dan nepotisme. Rekrutmen pegawai masih dipandang seakanakan mejadi kebutuhan proyek tahunan dan bukan sebagai kebutuhan akan peningkatan kualitas pelayanan publik dan penyelenggaraan pemerintahan. Indikasi ini sangat nyata apabila dilihat bahwa job analylis sebagai per-syaratan untuk menentukan job requitment masih belum dimiliki oleh pemerintah. Ketiadaan persyaratan jabatan telah menyebabkan rekrutmen dilakukan secara serampangan dan tidak memperhatikan kualifikasi yang dibutuhkan. Itu sebabnya, meskipun dirasakan Pegawai Negeri Sipil (PNS) di Indonesia tidak tahu apa yang dikerjakan, tetapi rekrutmen Calon Pegawai Negeri Sipil (CPNS) tetap terus dilakukan. Untuk dapat melakukan dengan baik proses perekrutan, maka spesifikasi tugas dan jabatan hares diketahui secara baik. Ironisnya, banyak sekali PNS yang tidak mengetahui kebutuh-an analisis jabatannya, Sumber saya manusia (SDM) aparatur pada satuan organisasi menjadi berlebihan dan tidak sesuai dengan beban kerja yang ada. Rekrutmen yang demikian akan semakin memperbanyak pengang-guran tidak kentara yang sesungguhnya berstatus sebagai Pegawai Negeri Sipil (PNS).

Pada sisi lainnya, kepastian tentang jumlah PNS yang dibutuhkan terhadap jumlah pendidik (risiko beban kerja) masih belum dapat dihitung secara baik untuk menentukan jumlah pegawai yang hares direkrut setiap tahunnya. Dari sisi penyelenggaraannya rekrutmen pegawai masih dilaku-kan dengan caracara yang tidak menjamin kesempatan dan terjaringnya calon-calon yang potensial. Hal ini disebabkan karena rekrutmen masih 


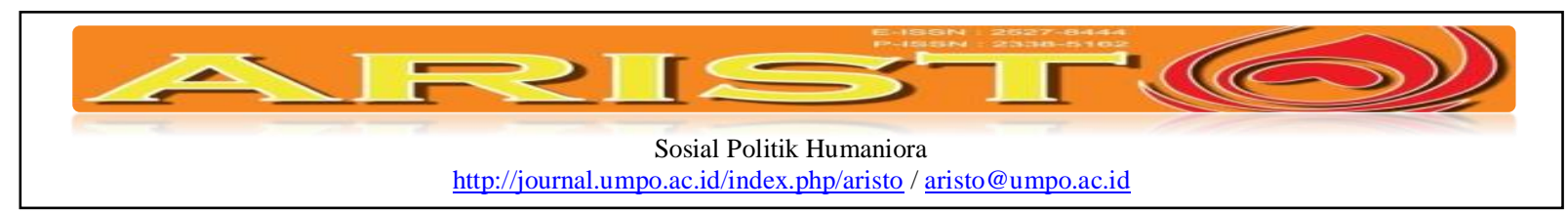

dilakukan pemerintah dan bukan oleh sebuah Iembaga yang independen (seperti civil service commission). Dengan situasi birokrasi yang sarat dengan Kolusi Korupsi Nepotisme (KKN), maka proses rekrutmen yang demikian tidak dapat menghasilkan calon-calon yang terbaik. Sudah menjadi rahasia umum bahwa proses rekrutmen di Indonesia dilakukan dengan cara-cara penyuapan, pertemanan dan afiliasi. Budaya perekrutan yang demikian hanya akan menghasilkan birokrat yang moralnya tidak terjaga dan kompetensinya yang tidak memadai. Problem perekrutan yang dilakukan oleh pemerintah daerah juga tidak bebas dari masalah. Kuatnya egoisme daerah dan masih menonjolnya hubungan-hubungan persaudaraan dan afiliasi, juga telah menyebabkan proses rekrutmen tidak menghasilkan PNS-PNS yang memenuhi syarat kualifikasi dan akhlak yang balk. Bahkan kecenderungan untuk menguta-makan putra daerah dalam perekrutan Calon Pegawai Negeri Sipil (CPNS) saat ini semakin menonjol. Itu sebabnya beberapa waktu lalu proses perekrutan Calon Pegawai Negeri Sipil (CPNS) di beberapa daerah telah menimbulkan demonstrasi dan situasi chaos Layanan Publik, Prasodjo (2006). Situasi problematik lainnya dalam perekrutan Calon Pegawai Negeri Sipil (CPNS) adalah kekuatan eksternal yang mendorong terjadinya intervensi politik dalam proses rekrutmen. hal ini disebabkan karena biro-krasi di Indonesia masih belum terpisah secara total dengan politik. Ke-inginan pihak-pihak tertentu misalnya partai politik untuk menjadikan birokrasi sebagai mesin politik, juga ikut mempengaruhi sukarnya mela-kukan reformasi rekrutmen Calon Pegawai Negeri Sipil (CPNS), Prasojo (2006). Paling tidak, komiitmen partai politik untuk mendorong terjadinya perubahan proses dan substansi rekrutmen akan membantu percepatan perbaikan rekrutmen Calon Pegawai Negeri Sipil (CPNS).

Persoalan kedua yang menjadi acuan dalam kepegawaian adalah sistem penggajian Pegawai Negeri Sipil (PNS). Tingkat kesejahteraan Pegawai Negeri Sipil (PNS) yang rendah sangat mempengaruhi kinerja dan perilaku Pegawai Negeri Sipil (PNS). Persoalannya terletak pada tidak seimbangnya antara kebutuhan yang harus dikeluarkan oleh seorang Pegawai Negeri Sipil (PNS) dengan gaji yang diterima. Hal senada jugs dikemukakan oleh Prasojo (2006) dan Efendi (1993) tentang masalah tersebut. Prasojo (2006) dan Efendi (1993) merincikan beberapa masalah dalam reformasi kepegawaian 


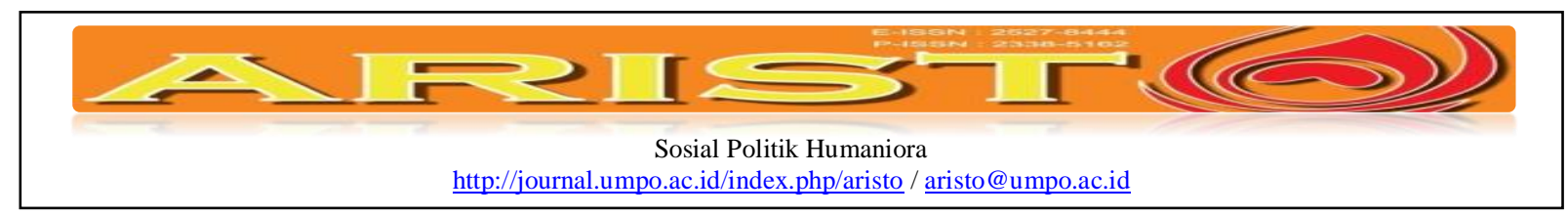

antara lain: Pertama, sistem rekrutmen pegawai yang dilakukan tanpa perencanaan yang matang yang didasarkan pada job analisis, standar kom-petensi, analisis kebutuhan yang nyata, proses seleksi dan penem-patan pegawai serta masih kuatnya nuansa politis terhadap rekrutmen pegawai. Kebijakan yang demikian memiliki implikasi yakni tidak terpenuhinya tuntutan 'the right man on the right place' dan pegawai yang tidak profesional, efektif dan efisien karena rekrutmen yang demikian Iebih condong kepada 'spoil system' daripada 'merit system'. Kuatnya egoisme daerah dan rriasih menonjolnya hubungan-hubungan persaudaraan dan afliasi, juga telah menyebabkan proses rekrutmen tidak menghasilkan Pegawai Negeri Sipil (PNS) yang memenuhi syarat kualifikasi dan ahlak yang baik. Bahkan kecenderungan untuk mengutamakan putra daerah dalam perekrutan Calon Pegawai Negeri Sipil (CPNS) saat ini semakin menonjol. Situasi problematik lainnya dalam perekrutan Calon Pegawai Negeri Sipil (CPNS) adalah kekuatan eskternal yang mendorong terjadinya intervensi politik dalam proses rekrutmen. Hal ini disebabkan karena birokrasi di Indonesia masih belum terpisah secara total dengan politik. Kedua, sistem penempatan atau alokasi yang tidak memenuhi standar kesesuaian kompetensi, dan keahliannya melainkan hanya dida-sarkan normative administrative yaitu kepangkatan dan golongan. Impli-kasinya sulit untuk melakukan pengembangan karir, karena pekerjaan yang dilakukan tidak sesuai dengan kompetensi dan keahlian yang dimilikinya. Selain sistem penempatan yang tidak sesuai kompetensi dan keahliannya, penempatan pegawai dan pengangkatan pegawai dalam jabatan dan 'penu-gasan juga Iebih banyak didasarkan pertimbangan like and dislike dengan mengabaikan keahlian profesi, pengetahun, dan penga-laman yang diperlu-kan organisasi. Ketiga, pola pengembangan aparatur yang belum diorientasikan pada sistem karir, dan tidak adanya rancana pengembangan karir secara jelas. Yang tertuang dalam kebijakan pengembangan karir, oleh karenanya diktat-diktat yang diselenggarakan tidak memiliki arah yang jelas, dan disamping itu jajaran birokrasi tidak dapat mengidentifikasikan kebutuhan jenis diktat yang dibutuhkan bagi pengembangan karir, sehingga diktat-diktat yang dilaksanakan selama ini tidak Iebih hanya merupakan sebuah program kegiatan. Keempat, sistem yang selama ini digunakan dalam penelitian kinerja pegawai adalah DP3, sehingga sangat sulit untuk mencari ukuran bahwa PNS di Indonesia memiliki karakter profesionalisme dalam 


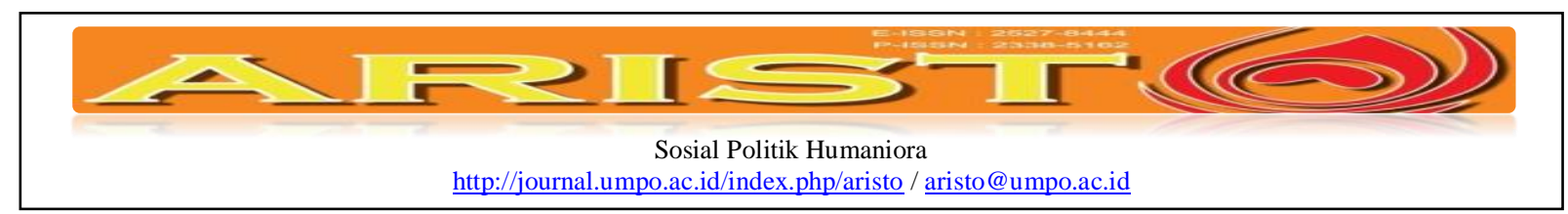

kinerja, hal ini dikarenakan ukuran-ukuran kinerja dalam DP3 sangat bersifat umum dan sangat memungkinkan memasukkan unsur-unsur like and dislike pimpinan kepada bawahan. Ketidakjelasan pengukuran kinerja mempunyai dampak berupa ketidakjelasan standart promosi jabatan, seseorang dipro-mosikan dalam bobotan tidak berdasarkan kinerjanya, tetapi Iebih ber-dasarkan kesetiannya dan kedekatannya dengan atasan. Sistem penilaian kinerja seperti ini tidak akan dapat memotivasi dan memompa aspirasi, mengembangkan inovasi dan sikap progresif pegawai, karenanya sistem penilaian ini justru bersifat kontra produktif. Kelima, sistem kenaikan pangkat, yang berjalan secara otomatis menjadikan pegawai bersikap apatis, pasif dan menerima apa adanya, tanpa ada suatu tantangan, untuk meningkatkan prestasi kerja. Implika-sinya adalah pegawai bekerja tanpa beban artinya bekerja hanya melakukan suatu kewajiban tanpa berpikir bagaimana cara meningkatkan prestasi kerja karena kenaikan pangkat tanpa memperthaikan prestasi kerja dan prestasi kerja hanya dilihat dari DP3 serta kenaikan pangkat diberla-kukan sama kepada setiap pegawai, kecuali mereka yang memegang jabatan struktural ataupun fungsional. Keenam, sistem penggajian atau imbalan yang diberikan sama sesuai dengan pangkat, ruang dan golongan, dan sudah menjadi rahasia umum bahwa gaji PNS di Indonesia dibayarkan sama tanpa mem-perhatikan dan mengakomodasi perbedaan prestasi kerja, tingkat kompe-tensi dan kinerja pegawai yang lebih baik. Dengan bahasa yang sangat lugas dapat disebut 'pinter goblok gaji sama (PGGS) akibatnya Pegawai Negeri Sipil (PNS) yang tidak jelas tugasnya atau yang bekerja asal-asalan dengan PNS yang rajin bekerja memiliki penghasilan sama, kondisi tersebut rentan menimbulkan kecemburuan sosial. Selain itu gaji yang diberikan kepada PNS, belum dapat memenuhi tingkat kesejahteraan Pedawai Negeri Sipil (PNS) karena tidak adanya keseimbangan antara gaji yang diterima dengan kebutuhan yang harus dikeluarkan, sehingga gaji yang diterima oleh pegawai tidak memberikan insentif bagi pelaksanaan kinerja semakin baik, dan gaji atau imbalan yang rendah dijadikan sebagai alasan terhadap buruknya kinerja pelayanan dan patologi birokrasi. Ketujuh, peraturan disiplin pegawai yang tidak mampu mengikat secara tegas, karena kurangnya pengawasan dari unsur pimpinan serta ketidakjelasan sistem rekrutmen, penggajian, pengukuran kinerja dan pro-mosi yang berdampak pada Iemahnya penegakan pengawasan terhadap perilaku dan pengawasan. 


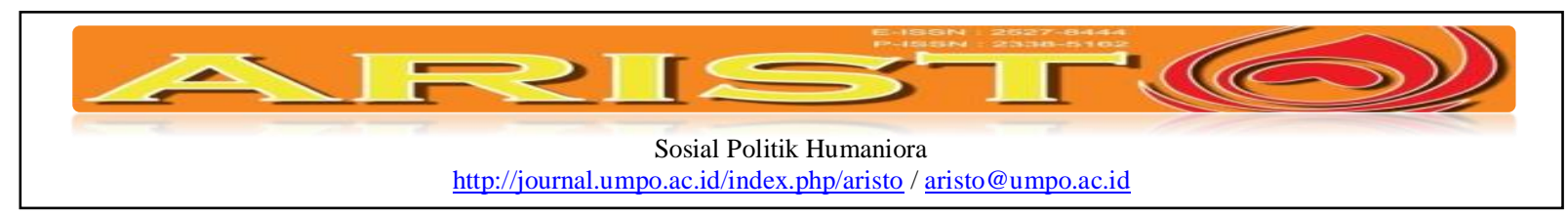

Sulitnya mengadakan pengawasan terhadap pegawai sehingga banyak pegawai yang melakukan pelanggaran disiplin de-ngan alasan kondisi ekonomi serta suasana kerja yang tidak kondusif, dan merupakan hal yang Iumrah apabila banyak Pegawai Negeri Sipil (PNS) yang melakukan bisnis di dalam jam kerja untuk menambah penghasilan dan kehadiran pegawai menjadi tidak penting lagi. tunjangan yang diterima Pegawai Negeri Sipil (PNS) semakin sulit diukur dan semakin tidak trans-paran. Sumber-sumber pembiayaan gaji pun sangat beragam sehingga membuat income seseorang dalam jabatan negara tidak transparan. Bahkan besarnya gaji yang diterima oleh Pegawai Negeri Sipil (PNS) hanya berkisar 20-30 persen dari take home pay yang diterima oleh seseorang Pegawai Negeri Sipil (PNS). Ini pula yang menyebabkan pemberian suap dan gratifikasi pelayanan publik dan penyelenggaraan pemerintahan.

Hal lain yang turut mewarnai carut marutnya sistem penggajian Pegawai Negeri Sipil (PNS) di Indonesia adalah koneksi sistem penggajian dengan sistem penilaian kinerja. Sudah menjadi rahasia umum, bahwa gaji PNS di Indonesia dibayarkan secara sama tanpa memperhatikan kinerja yang dilakukan. Dengan bahasa lugas, seringkali disebut 'pinter goblok, penghasilan sama (PGPS). Tidak berlebihan untuk mengatakan hal tersebut, bahkan seorang Pegawai Negeri Sipil (PNS) yang tidak memiliki tugas pasti, juga mendapatkan gaji seperti halnya Pegawai Negeri Sipil (PNS) yang melaksanakan tugas dengan baik. Akhirnya seringkali gaji yang diterima Pegawai Negeri Sipil (PNS) tidak memberikan insentif bagi pelaksanaan kinerja yang semakin baik. Dalam pengertian lain, sistem penggajian Pegawai Negeri Sipil (PNS) beium berdasar pengukuran kinerja. Hal ini pula yang mematikan kreativitas dan inovasi Pegawai Negeri Sipil (PNS) dalam bekerja. Ketiadaan analisis jabatan dan kiasifikasi jabatan menyebabkan penggajian masih belum berbasis pada bobot pekerjaan. Selanjutnya terkait erat dengan persoalan kepegawaian negara adalah sistem penilaian kinerja. Sangat sulit mencari ukuran untuk mengatakan bahwa Pegawai Negeri Sipil (PNS) di Indonesia memiliki karakter profesioanalisme dalam kinerja. Karena profesionalisme dalam kinerja memiliki ukuran-ukuran yang bisa secara kuantitatif terukur dan dapat diperbandingkan. Selama ukuran yang dijadikan sebagai indikator kinerja seorang Pegawai Negeri Sipil (PNS) adalah daftar penilaian prestasi pegawai (DP3) maka sulit rasanya mengukur kinerja Pegawai Negeri Sipil (PNS). Hal ini 


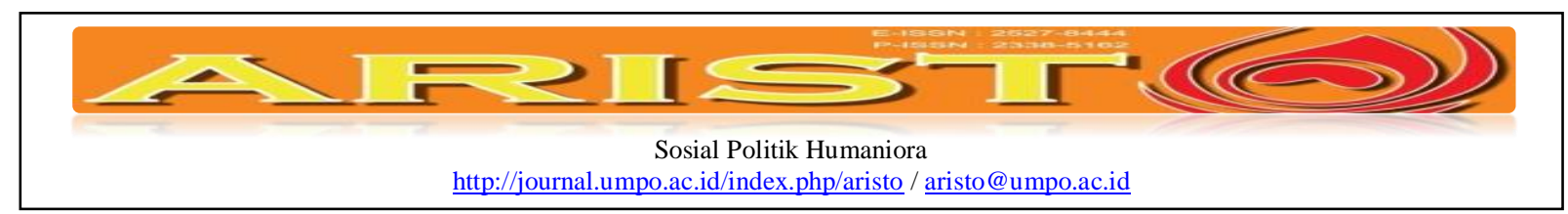

karena ukuran-ukuran kinerja dalam DP3 sangat bersifat umum dan sangat memungkinkan memasukkan unsur-unsur like and dislike pimpinan kepada bawahan. Ketidakjelasan pengukuran kinerja mempunyai dampak berupa ketidakjelasan standar promosi jabatan. Seseorang dipromosikan dalam jabatan tidak berdasarkan kinerjanya, tetapi lebih berdasarkan kesetiaannya dan kedekatannya dengan seorang atasan, bahkan sampai saat ini kita tidak memiliki stock nama pejabat dan pegawai dengan kompetensi dan kinerja yang menjadi dasar promosi jabatan.

Persoalan internal dalam sistem kepegawaian adalah lemahnya pengawasan terhadap perilaku dan disiplin pegawai. Sebagai suatu sistem maka sub sistem kepegawaian saling terkait. Artinya ketidakjelasan sistem rekrutmen, penggajian, pengukuran kinerja dan promosi juga berdampak pada pengawasan terhadap perilaku dan disiplin pegawai. Keterkaitan ini ibarat lingkaran setan yang sulit ditentukan ujung pangkalnya. Lemahnya penegakan pengawasan disebabkan oleh ketiadaan standar kinerja, rendahnya gaji, dan promosi yang kental dengan afiliasi. Dalam praktiknya yang terjadi adalah sulitnya mengawasi membengkaknya kekayaan dan harta pegawai, penerimaan hadiah dan gratifikasi menjadi hal yang Iumrah dan kehadiran pegawai menjadi tidak penting lagi. Secara eksternal carut marutnya sistem kepegawaian di Indonesia juga diwarnai oleh kooptasi partai politik terhadap Pegawai Negeri Sipil (PNS). Ketidaknetralan Pegawai Negeri Sipil (PNS) seringkali menye-babkan penyalahgunaan kewenangan oleh pejabat dan Pegawai Negeri Sipil (PNS). Sulitnya membedakan antara tugas sebagai Pegawai Negeri Sipil (PNS) dan keberpihakannya pada partai politik, menyebabkan sistem kepegawaian tidak lagi berdasarkan kepada sistem merit, tetapi kepada spoil system. Anggaran negara tidak digunakan semestinya melainkan atas kepentingan-kepentingan afiliasi politik. Promosi jabatan juga dilakukan atas dasar kedekatan hubungan dengan kolega dan pertemanan politik. Sebagaimana dikemukakan oleh Thoha (2005) kondisi kepegawaian yang ada saat ini tidak bisa dipisahkan dari kebijakan penerimaan pegawai di masa lalu, karena proses penataan kepegawaian mulai dari rekturmen, pembinaan dan pensiun banyak diwarnai aroma politik dimana pemerintah membutuhkan pegawai karena didorong oleh keinginan untuk memper-banyak jumlah sehingga semakin banyak pegawai yang bisa dibina untuk mendukung kekuatan golongan 


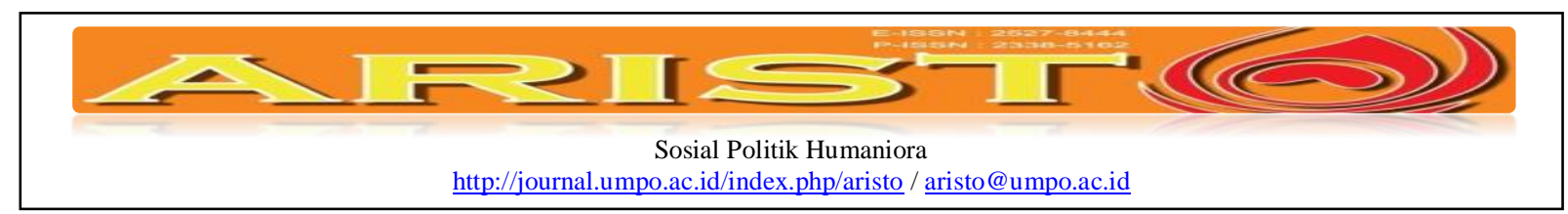

politik tertentu.

Baik problem internal sistem kepegawaian maupun problem kooptasi politik terhadap birokrasi akan mempengaruhi kinerja birokrasi secara keseluruhan, karena beberapa reformasi kepegawaian harus diarahkan untuk mewujudkan Pegawai Negeri Sipil (PNS) yang profesional, indepen-den dan berbudaya melayani masyarakatnya. Konsep sistem penyelenggaraan pemerintahan daerah yang me-makai metode desentralisasi mempunyai kewenangan yang sangat luas, yang merupakan antitesa pembangunan dan pemberdayaan daerah sesuai dengan perkembangan kondisi masyarakat Indonesia saat ini yang sedang belajar dan mengembangkan demokrasi di berbagai segi, khususnya demokrasi politik. Desentralisasi merupakan proses pengurangan atau peng-hapusan peran dan wewenang pemerintah pusat guna menciptakan pem-berdayaan pemerintah daerah dan masyarakat daerah untuk bisa me-ngembangkan daerahnya secara mandiri. Otonomi daerah atau de-sentralisasi merupakan dua hal yang saling melengkapi dengan semua sudut multidimensi yang melingkupinya.

Sejak diberlakukannya Undang-undang Nomor 32 Tahun 2004 tentang Pemerintahan Daerah, terjadi perubahan kebijakan yang mendasar di bidang kepegawaian. Perubahan kebijakan tersebut merupakan salah satu bagian dari reformasi administrasi, Caiden (1969). Reformasi admi-nistrasi. pada hakekatnya menyangkut dimensi dan spektrum yang sangat luas serta bertujuan sangat jelas yaitu meningkatkan administrative perfor-mance dari birokrasi pemerintah, Caiden (1970). Reformasi administrasi di bidang kepegawaian antara lain perubahan tentang kewenangan peng-angkatan, pemindahan dan pemberhentian Pegawai Negeri Sipil yang semula merupakan kewenangan pemerintah pusat, maka pada era otono-mi daerah kewenangan tersebut merupakan kewenangan pemerintah kabupaten dan kota. Pengangkatan Calon Pegawai Negeri Sipil Daerah diatur dalam Undang-Undang Nomor 43 Tahun 1999 tentang Pokok-Pokok Kepegawaian, yang ditindaklanjuti dengan Peraturan Pemerintah Nomor 98 tahun 2000 juncto Peraturan Pemerintah Nomor 11 Tahun 2002 tentang Pengadaan Pegawai Negeri Sipil. Kewenangan pengangkatan Calon Pegawai Negeri Sipil (CPNS) sebelum dikeluarkannya undangundang tersebut merupakan kewenangan pemerintah pusat namun setelah dikeluarkannya Undang-Undang Nomor 32 Tahun 2004 maka kewenangan pengangkatan 


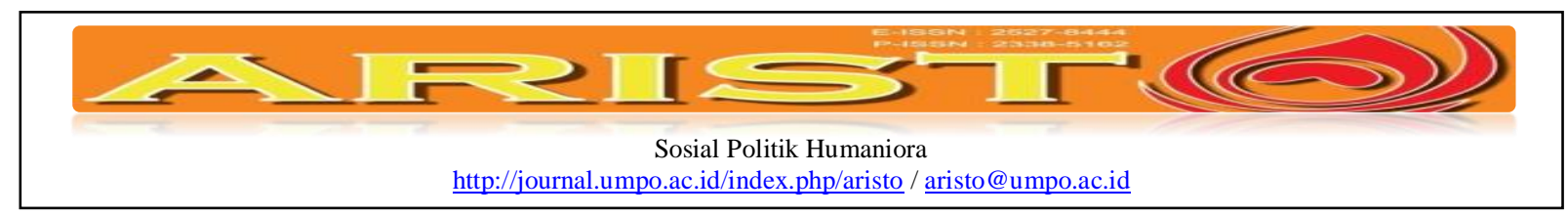

Pegawai Negeri Sipil (PNS) diserahkan kepada Kabupaten dan Kota. Hal ini sebagaimana dijelaskan Warsito (2006), berikut ini:

"Dan meskipun pasal 129 Undang-Undang Nomor 32 Tahun 2004 mengatakan bahwa pemerintah melaksanakan pembinaan manaje-men pegawai negeri sipil daerah yang meliputi penetapan formasi, pengadaan, pengangkatan, pemindahan, pemberhentian, pene-tapan pensiun, gaji, tunjangan, kesejahteraan, hak dan kedu-dukan, pengembangan komptensi dan pengendalian jumlah, itu-lah yang juga menjadi pelaksanaan tugas dari BKD di daerah".

Berdasarkan kriteria pembagian urusan yang dijelaskan dalam Undang-Undang Nomor 32 Tahun 2004 tentang Pemerintahan Daerah, Bab III (Pasal 10 s.d. Pasal 18) tentang Pembagian Urusan Pemerintahan, maka kewenangan masing-masing tingkatan pemerintahan adalah sebagai beri-kut: a. Pusat: berwenang membuat norma-norma, standar, prosedur, moni-toring dan evaluasi, supervisi, fasilitasi, pengawasan dan urusan-urus-an pemerintahan dengan eksternalitas nasional; b. Provinsi: berwenang mengatur dan mengurus urusan-urusan pemerintahan dengan eksternalitas regional (lintas Kabupaten/Kota); c. Kabupaten/Kota: berwenang mengatur dan mengurus urusan-urusan pemerintahan dengan eksternalitas lokal (dalam satu Kabupaten/Kota). Pembagian kewenangan tersebut termasuk berlaku dalam konteks manajemen sumber daya aparatur publik. Dalam konteks Negara Kesatuan Republik Indonesia (NKRI) dan sistem desentralisasi, maka pemerintah pusat memainkan kebijakan yang bersifat penentuan standar, norma, prosedur, monitoring dan pengawasan. Sedangkan pemerintah daerah menjalankan sepenuhnya manajemen kepegawaian daerah.

\section{Kesimpulan}

Internalisasi nilai-nilai demokrasi dalam reformasi kepegawaian publik, karena administrasi publik sesungguhnya dipandang sebagai bagian dari aktivitas masyarakat, sebab birokrasi dan organisasi pemerintah merupakan bagian dari dan berkaitan erat dengan sistem politik, sosial, ekonomi, dan se-bagainya. Adanya internalisasi nilainilai demokrasi akan berimplikasi pada terkonstruksinya pola bottom up didalam proses dan pelaksanaan sistem rekruitmen Calon Pegawai Negeri Sipil (CPNS) dan fidak semata-mata top down dengan tetap mengadopsi teori merit system Leveriza (1990). Dan Undang-Undang Pendleton 2301 huruf (b) bab 5 Tentang konsep Merit system. 


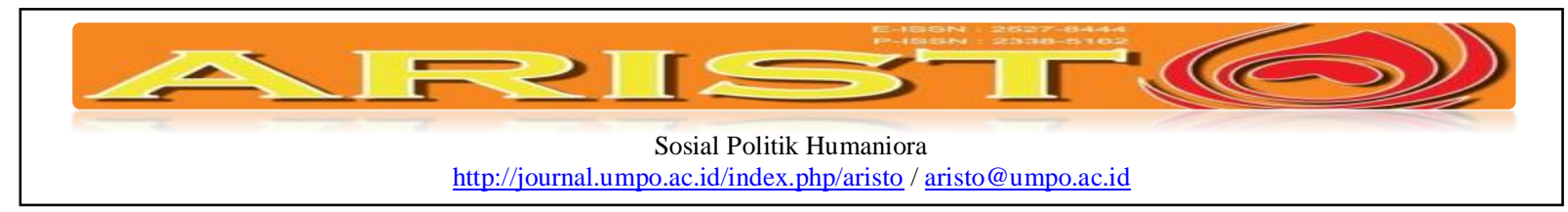

\section{DAFTAR PUSTAKA}

Antoft, K. \& Novack, J. 1998, Grassroots Democracy : Local Government in the Maritimes, Nova Scotia: Henson College. Dalhousie University.

Baedhowi. 2007. Revitalisasi Sumber Daya Aparatur dalam Rangka Meningkatkan Kualitas Layanan Publik. Jurnal Ilmu Administrasi dan Organisasi, Bisnis \& Birokrasi, Vol.15, No.2 (Mei).

Bryant, Coralie \& White Louise.1987.Manajemen Pembangunan untuk Negara Berkembang. LP3ES.Jakarta.

Islamy, Irfan 1998, Agenda Kebijakan Reformasi Administrasi Negara, Naskah Pidato Guru Besar Ilmu Kebijakan Publik, FIA Universitas Brawijaya Malang.

2001. Agenda Kebijaksaan Reformasi Administrasi Negara. Journal Administrative Negara: Good Governance, Vol. II No 1, September 2001. FIA Unibraw Malang.

Irawan, Prasetya, Suryani S.F.Motok, Sri Wahyu Krida Sakti, 1997 Manajemen Sumber Daya Manusia, Jakarta: STIA LAN Press.

Ivancevich, John M. 2001, Human Resource Management, New York: Mc. Grow Hill Companies.

Mathis. Robert I, Jackson John H. 2001. Manajemen Sumber Daya Manusia, Jakarta: Salemba Empat.

Mathis, Robert L and John H Jackson. 2000. Human Rosources Management, Nineth Edition, South-Western College Publishing United State.

2002, Manajemen Sumber Daya Manusia. Terjemahan oleh Jimmy Sadeli. Salemba Empat. Jakarta.

Mawhood, Philip. 1983. Decentralization : the Concept and the Practice: in Philip Mawhood, Local Government in the Wolyd: the Experience of Tropical Africa, First Edition, John Wiley \& Sons Ltd, Afrika Selatan. 1987. Local Government in the Third World, John Wiley \& Sons: New York.

Mondy, Wayne \& Robert M, Noe. 1996. Human Resource Management, New Jersey: Prentice Hall Inc.

Mondy, Wayne \& Robert M, Noe. 1996. Human Resource Management, New Jersey: Prentice Hall Inc. 


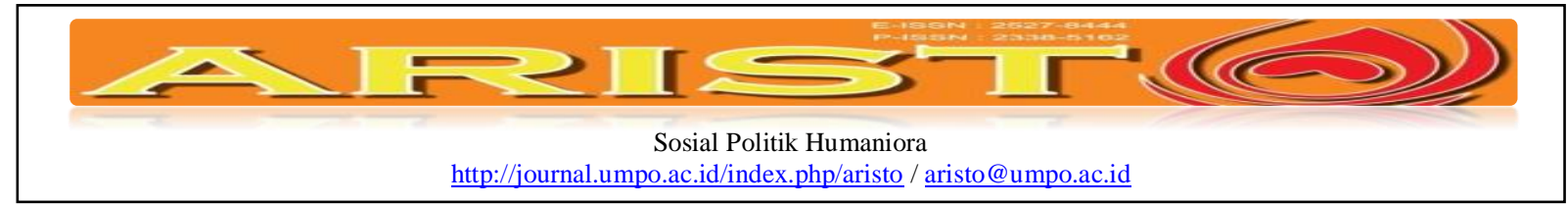

Muluk, Khairul MR. 2000. Reformasi Manajemen Personalia Publik, Journal I Adminsitrasi Negara. Vol 1. No 1, September 2000. FIA Unibraw MalangAdministrasi Negara.

Muluk, Khairul, M. R. 2009. Peta Konsep Desentralisasi dan Pemerintahan Daerah, ITS Press. Surabaya.

Pamudji, Suparni, (1984), "Pelaksanaan Asas Desentralisasi dan Otonomi Daerah di dalam Sistem Administrasi Negara Republik Indonesia", Pidato Pengukuhan Guru Besar Ilmu Administrasi Negara, Jakarta: Institut Ilmu Pemerintahan.

Sondang P. Siagian, 1994. Manajemen Sumber Daya Manusia, Jakarta: Bumi Aksara,

Shafritz, Jay M and E.W. Russel.1996. Introducing Public Administration. Addison-Wesley Publishing Company.

2002. Manajemen Sumber Daya Manusia. Jakarta: Bumi Aksara.

Simamora, Henry.1999.Manajemen Sumber Daya Manusia.Yogyakarta:YKPN

Syamsudin, Sadili (2006); Manajemen Sumber Daya Manusia, Bandung: Pustaka Setia/

Tjokroamidjojo, B. 1987. Pengantar Administrasi Pembangunan. LP3ES,Jakarta.

\section{Referensi Dari Internet}

http://www.indonesia.go.id/in/lpnk/badan-kepegawaian-negara/2477-profile/363-badan-

kepegawaian-negara

www.bkn.go.id. Proses Perekrutan CPNS di Indonesia.

www.fajar.co.id. Mekanisme Penerimaan CPNS secara Nasional.

www.waspada.co.id. CPNS dan Mental Wiraswasta. 